\section{MALC IN ILLINOIS}

The twelfth annual Midwest Academic Librarian's Conference, held at the University of Illinois Chicago Circle on May 5-6, was attended by more than three hundred librarians representing states from Ohio to Kansas.

The program began Friday afternoon with a talk by Robert Asleson, general manager of University Microfilms on "The Future Interrelationship Between the Photocopying Industry and College and University Libraries." Richard Chapin, director of the Michigan State University library and William Buddington, librarian of the John Crerar library served as commentators on Mr. Asleson's talk. In his remarks Mr. Asleson observed that the Xerox Corporation, his parent firm, was a "communication industry" interested in branching out into the field of education. University Microfilms, the first educational organization acquired by Xerox, is an "on demand" industry which pioneered the use of $35 \mathrm{~mm}$ microfilm for the preservation and duplication of library materials.

In reviewing the current activities of University Microfilms, Mr. Asleson mentioned the following:

1. "Periodicals on microfilm" is one of the firm's fastest growing programs.

2. The DATRIX project-an acronym for Direct Access to Research Information-will provide libraries with information relating to specific research topics covered in the eighteen to twenty thousand dissertations now being produced in the United States each year. The title and subject matter of all dissertations in the files of University Microfilms are now on a computer and answers to inquiries about the identity of particular dissertations are being accepted.

3. University Microfilms now has a team in Europe microfilming manuscripts in Benedictine monasteries.

4. University Microfilms has several reprint projects underway.

University Microfilms explored the potential uses of all types of microreproduction but considers that $35 \mathrm{~mm}$ microfilm still seems to offer the best technology available. They are now investigating materials in cartridge form. Looking ahead, Mr. Asleson saw a need to provide copies of books now being published, twenty to thirty years hence. As a result University Microfilms is now arranging with several publishers to copy books as they are published. In the future, out-of-print books will be less of a problem. Another project being investigated by University Microfilms is the possibility of printing out professors' reserve lists.

In speaking of new equipment Asleson mentioned that better microfilm readers and printers were being designed particularly for libraries by University Microfilms and the Xerox Corporation. University Microfilms started with their $\$ 100$ reader-now other companies have seen the need and will also be bringing out inproved, low-cost equipment. Xerox has an improved reader-printer which will soon be ready for the market. In his remarks Mr. Buddington noted the importance of maximizing the availability of library materials. He observed that several problems were involved: (1) Copyright; (2) Varying formats-microcard, microprint, microfiche, microfilm; (3) The impact of federal funds; (4) The need for better bibliographic control of materials.

Mr. Chapin wondered why libraries couldn't cooperate at considerably less cost to do the work University Microfilms is doing for profit, and suggested that the library profession should go into competition with Xerox. In a short rebuttal Mr. Asleson reminded his audience that it was industry that put dollars into microfilm projects and that librarians were not noted for their success in undertaking cooperative projects. $\mathrm{He}$ believed University Microfilms could do the job cheaper and better than the library profession. In answer to questions from the floor he reported that iDATRIX costs $\$ 5$ per inquiry, for which ten titles are reported.

Walter Netsch Jr., discussed the "Transition in Library Design Since WVorld War II and Its Implications for the Future" at the Friday evening banquet. Rather than cliscuss the "nuts and bolts" aspects of library design, .Mr. Netsch chose to discuss more theoretical considerations. In summary, Mr. Netsch observed that the traditional concept of an individual study carrel as adequate for the library needs of students was no longer valid. Libraries must be designed to provide ready access to all types of information in a variety of media-the printed page, the cathode ray tube, motion pictures, microreproductions-and other media yet to be developed.

In dicussing project INTREX Mr. Netsch stated that this was-as the acronym impliesstill experimental. INTREX, which takes advantage of the multiple access computer, is not a model library but what Mr. Netsch termed a mixed media laboratory in which users will obtain information from several media sources. Surprising to some perhaps was Mr. Netsch's statement that one-fifth the area of the remodeled engineering library at Massachusetts Institute of 'Technology was required for machine access equipment.

Another unusual feature of Intrex development is the fact that the entire library has controlled lighting, i.e., the lighting level can be changed by means of a rheostat to any desired intensity. This is not a new idea and is being used more and more frequently for microform reading areas in libraries. What is new is its extension to the entire library. 
One of the objectives of the INTREX experiment, Mr. Nesch pointed out, is to develop equipment that can be decentralized around the campus so that each academic department can have more convenient access to the information its faculty and students require.

Finally, Mr. Netsch observed that libraries need similar mixed media facilities-he used the word laboratories-in the library of the future. He suggested that we need spaces in the library that will enable students in the humanities to assemble data or information in the same way and from the same variety of sources as does the student in the physical sciences.

Of special interest to many in the audience was the Saturday morning program in which Mrs. Henriette Avram discussed "The Library of Congress and the MARC Project" and Hillis Griffin of the Argonne national Jibrary responded by reporting on his library and its experience as a user of MARC materials.

Mrs. Avram was introduced by Allen Hogden, head of cataloging at University of Illinois, Chicago Circle. In his introduction, Mr. Hogden pointed out that we can no longer afford the luxury of cataloging the same book in hundreds of different libraries with all the waste of time and money that such duplication of effort implies. The alternative is to depend upon centralized services for cataloging data, such as those of the Library of Congress.

Mrs. Avram noted that MARC started with 1965 Conference on Machine Readable Catalog Copy. By June 1965, the Library of Congress' Information Systems Office had prepared a memo discussing the problems of converting bibliographic data to machine readable form. The basic requirement was recognition of the need for a standardized format that would serve library needs with the greatest degree of flexibility. In December 1965, LC received a grant from the Council on Library Resources for systems planning, the preparation of computer programs, and systems evaluation. LC's own funds were to be used for operation of the system. LC decided to use its own equipment and to operate the project on site at LC. Materials for the experiment were all English language monographs.

From a list of thirty-seven libraries sixteen, representing a cross section of the various types of libraries, were chosen as participants in the project. Implementing the MARC project required a set of procedures and computer programs. By preparing basic computer problems, LC helped to stimulate the participants to further experimentation.

Some forty-three programs containing thirtythree thousand instructions were written to implement the program. Because of equipment and programing, the project was not started until the week of November 24, 1966. To date,
LC has distributed twenty-seven weekly tapes containing about eleven thousand MARC records, eleven thousand author/title records, two hundred and forty-five subject cross reference tracing records, and seven hundred and fortyeight descriptive cross reference tracing records.

MARC is still in pilot stage. The idea of regional libraries has been developed and sharing of tapes has been encouraged. As a result, MARC now has twenty-three secondary participants. Originally, LC planned to continue MARC through June 1967. Now, because of wide interest, it is planned to continue and expand the project.

Hillis Griffin of the Argonne national library discussed the user's reactions to the MARC project. His organization received first program from LC in November 1966, he said. Although the computer program was prepared by LC, it was necessary to modify it to get a suitable printout on the Argonne computer. They wrote other experimental programs as LC had hoped would be the case. Mr. Griffin emphasized that MARC is still experimental. Given proper equipment, the tapes have the possibility of printing out with upper and lower case and diacritical marks. Manipulation of bibliographic data still poses some difficult problems, and cannot be done overnight. He cautioned libraries not to think they could do this easily. Mr. Griffin observed that the use of automation for cataloging will probably not be feasible for all libraries for many years. He suggested the use of a cataloging sign-up system whereby a library could request cataloging data for a particular title from a central computer store.

For the MARC project to be successful Mr. Griffin stated that libraries should become active partners with LC in this effort, rather than passive customers. In summary Mr. Griffin was enthusiastic about the potential effectiveness and usefulness of the project.

Maurice Boatman, librarian, Millikin University, Decatur, Ill., will be next year's MALC chairman. Place and dates have not yet been determined.-Frazer Poole.

\footnotetext{
ACRL Conference Highlights will appear in the July-August issue of the ALA Bulletin.
} 